\title{
Election fever inflames the US stem-cell debate
}

In the run-up to autumn's Senate elections, stem-cell research has become something of a political football. This is raising the profile of bills that could loosen restrictions on federal funding for the research, but some fear that scientific arguments are being overshadowed by politicians' posturing.

In November, voters will decide who occupies 33 seats in the Senate and 435 in Congress, and stem cells are poised to play a decisive role in some key races.

Last May, the US House of Representatives voted overwhelmingly to loosen restrictions on federal funding of human embryonic stemcell research. Since then, the Republican Senate majority leader, Bill Frist, has faced demands from stem-cell research advocates to deliver on a promise to bring the issue to the Senate floor (see Nature 436, 608; 2005).

Observers say Frist must factor numerous political considerations into his decision about when and how to bring the issue before the Sen- ate, including how it would be viewed by the White House and how it would affect his own career. The issue has become difficult for the Republican party because although a majority of voters support the work, it is viewed as immoral by the party's conservative core.

Washington is buzzing with rumours. Last week, Associated Press reported that senators are deciding whether to vote on a package of three stem-cell bills later this summer. But no senator has confirmed the story, leaving advocates uncertain what this will mean for research. "Only the details will determine whether it is good or bad for researchers and, ultimately, patients," says Kevin Wilson, director of public policy at the American Society for Cell Biology.

The package would comprise the bill passed by the House and two others, one of which was introduced on 5 May by Pennsylvania senators Arlen Specter and Rick Santorum, both Republicans. Their bill supports research that tries to find sources for human embry- onic stem cells that do not harm embryos.

The deal might help Santorum, who faces a bruising re-election battle this autumn. But it is undear how the bill would affect other races.

The White House, meanwhile, stands by President George W. Bush's threat to veto any bill that loosens restrictions on federal funding for stem-cell research. Some say such a veto may actually help Bush win some badly needed points. The Christian right is beating him up, says one research advocate, speaking off the record. "The White House needs to put a stop to that, and this would do it."

Such a scenario would not help researchers much. And some in the research community are nervous about the effect this political manoeuvring could have on science. ${ }^{\alpha}$ These are complicated, cutting-edge scientific issues, and they need to be considered in a thoughtful and educated manner," says Wilson. "In general, this is not the best way to legislate."

Erika Check 